\title{
Aktualizacja opłat rocznych z tytułu użytkowania wieczystego w świetle ustawy z dnia 20 lipca 2018 r. o przekształceniu prawa użytkowania wieczystego gruntów zabudowanych na cele mieszkaniowe w prawo własności tych gruntów
}

Updating Annual Fees regarding Perpetual Usufruct in the light of the Regulation from 20th July 2018 on Transformation the Right of Perpetual Usufruct of built-up area for residential purposes into Ownership Title of such area

Обновление ежегодной платы за бессрочное пользование в свете Закона от 20 июля 2018 года о преобразовании права бессрочного пользования землей, застроенной для жилищного строительства, в право собственности на такую землю

\author{
MAREK STAWECKI \\ Dr, Uniwersytet Szczeciński \\ e-mail: marekstawecki@op.pl, https://orcid.org/0000-0002-3598-7787
}

\begin{abstract}
Streszczenie: W dniu 5 października 2018 r. weszła w życie ustawa z dnia 20 lipca 2018 r. o przekształceniu prawa użytkowania wieczystego gruntów zabudowanych na cele mieszkaniowe w prawo własności tych gruntów (Dz. U. z 2020 r. poz. 139 z późn. zm.). Skutkiem jej jest również konieczność uiszczania tzw. opłat przekształceniowych. Wysokość ich jest równa wysokości opłat rocznych z tytułu użytkowania wieczystego, które obowiązywałyby w dniu przekształcenia. Te ostatnie podlegają tzw. aktualizacji. W 2019 r. dokonano zmiany ww. ustawy, którą należy ocenić jako niesprawiedliwą. Nałożyła się bowiem ona na trwające w jednostkach samorządu terytorialnego procedury aktualizacji. W okresie tym były już wszczęte oraz wszczynano kolejne postępowania aktualizacyjne, których efektem jest podwyższenie wysokości opłat rocznych z tytułu użytkowania wieczystego gruntów zabudowanych na cele mieszkaniowe, a w konsekwencji także i opłat przekształceniowych. W artykule wskazano, iż omawiana regulacja prowadzi w konsekwencji do nieuzasadnionego obniżenia opłat lub nieuzasadnionego zakończenia postępowań aktualizacyjnych w stosunku do wszystkich współużytkowników wieczystych danej nieruchomości. Stanowi ona nadmierną i nieuzasadnioną ingerencję ustawodawcy w samodzielność finansową jednostek samorządu terytorialnego. Godzi również w konstytucyjnie zagwarantowaną ochronę „interesów w toku”. Ponadto sama redakcja omawianej regulacji w ustawie zmieniającej wywołuje wątpliwości interpretacyjne. Nie wiadomo bowiem, jakich dokładnie postępowań ona dotyczy. Problem ten jest konsekwencją dużego skomplikowania materii przekształcenia w kwestii skutków prawnych, nieprzejrzystości unormowań, a ponadto niedostrzegania przez prawodawcę ważnych problemów związanych z regulowaną materią. W artykule przeanalizowano i oceniono najnowsze zmiany legislacyjne prowadzące do przekształcenia prawa użytkowania wieczystego w prawo własności. Metodą badawczą, którą zastosowano w pracy, jest analiza aktów prawnych oraz orzecznictwa sądowego.
\end{abstract}

Słowa kluczowe: aktualizacja, użytkowanie wieczyste, przekształcenie, opłata roczna z tytułu użytkowania wieczystego, uwłaszczenie

Summary: The Regulation from 20th July 2018 on Transformation the Right of Perpetual Usufruct of built-up area for residential purposes into Ownership Title came into force on 5th October 2018 (Journal of Law 2020 
it.139 with further amendments). The consequence of this regulation is the necessity to pay so-called 'transferring fees.' Their amount is equal to the total amount of annual fees that resulted from perpetual usufruct which would be binding on the transferring day. The latter ones are subject to so-called updating. In 2019 the amendment to the above-mentioned regulation was made which is deemed unfair. It is because this amendment overlapped with updating proceedings that were taking place in the local authority units. In this period further updating proceedings had been already opened or about to be opened, the result of which is raising the total amount of annual fees resulted from perpetual usufruct of build-up areas for residential purposes, and as a consequence in raising the 'transferring fees'. The purpose of this article is to prove that the above-mentioned regulation leads to unjustified lowering in fees or unjustified ceasing the updating proceedings towards all the perpetual co-usufructuaries of a given property, which constitutes an excessive and unjustified interference of a legislator into financial autonomy of local authority units. It also acts to the detriment of a constitutionally guaranteed protection of 'business in progress'. Besides, the very wording of this regulation in the amendment rises doubts in interpretation - it is hard to deduce which proceedings it precisely applies to. This problem is the consequence of a highly complex character of the transformation matter with regards to its legal effects, the ambiguity of regulations, and above all, to the fact that legislators do not seem to notice relevant issues connected to the above matter. In this article, I analyse and evaluate the latest legislative changes leading to transforming the right to perpetual usufruct into an ownership title. The research method applied for the purpose of this article is the analysis of current laws and regulations as well as selected judicial decisions.

Key words: updating, perpetual usufruct, transformation, annual perpetual usufruct fee, enfranchisement

Резюме: 5 октября 2018 года вступил в силу Закон от 20 июля 2018 года о преобразовании права бессрочного пользования землей, застроенной для жилищного строительства, в право собственности на такую землю (Законодательный вестник 2020 года, ст. 139, с изменениями). Это, в свою очередь, приводит к необходимости уплаты так называемых преобразовательных сборов. Сумма этих сборов равна годовой плате за бессрочное пользование, которая подлежала бы уплате на дату преобразования. Сумма сборов подвергается так называемым обновлениям. В 2019 году в вышеупомянутый закон были внесены изменения, которые следует считать несправедливыми. Это объясняется тем, что он пересекается с процедурами обновления, находящимися на рассмотрении в местных органах самоуправления. В этот период уже были инициированы и продолжены процедуры обновления, в результате которых была увеличена ежегодная плата за бессрочное пользование землей, застроенной для жилищного строительства, и, соответственно, сборы за преобразование. В статье отмечается, что данное положение приводит к необоснованному снижению платы или необоснованному прекращению процедуры обновления в отношении всех бессрочных сопользователей данного имущества. Это является чрезмерным и необоснованным вмешательством законодателя в финансовую самостоятельность органов самоуправления. Это также нарушает гарантированную Конституцией защиту «интересов в прогрессе». Более того, сама формулировка рассматриваемого положения в законе о внесении поправок вызывает сомнения в толковании. Это связано с тем, что неизвестно, какого именно производства оно касается. Данная проблема является следствием большой сложности предмета преобразования с точки зрения правовых последствий, непрозрачности нормативных положений, а также неспособности законодателя заметить важные проблемы, связанные с регулируемым вопросом. В статье анализируются и оцениваются последние законодательные изменения, приведшие к преобразованию права бессрочного пользования землей в право собственности. Метод исследования, использованный в статье - анализ правовых актов и судебных решений.

Ключевые слова: обновление, бессрочное пользование, преобразование, ежегодная плата за бессрочное пользование, передача земли в собственность 


\section{Wstęp}

W dniu 5 października 2018 r. weszła w życie ustawa z dnia 20 lipca 2018 r. o przekształceniu prawa użytkowania wieczystego gruntów zabudowanych na cele mieszkaniowe w prawo własności tych gruntów (dalej: ustawa lub u.p.u.w.) ${ }^{1}$. Zgodnie z nią z dniem 1 stycznia 2019 r. prawo użytkowania wieczystego przekształciło się w prawo własności tychże gruntów ${ }^{2}$. Przekształcenie powiązane zostało z charakterem obiektów usytuowanych na gruncie. Może do powyższego dojść, jeżeli brak jest wątpliwości, czy to prawnych czy faktycznych, co do tego, że jest to grunt zabudowany na cele mieszkaniowe, a więc zabudowany obiektami o przeznaczeniu mieszkaniowym ${ }^{3}$. Nim doszło do tego skutku, ww. akt prawny został znowelizowany ustawą z dnia 6 grudnia 2018 r., która weszła w życie w dniu 1 stycznia 2019 r. ${ }^{4}$ Nie była to jednakże ostatnia zmiana ustawodawcza, ustawą z dnia 31 stycznia 2019 r. znowu bowiem dokonano nowelizacji ${ }^{5}$. Ta zmiana jednakże odnosiła się do już obowiązujących przepisów.

Skutkiem przekształcenia użytkowania wieczystego w prawo własności jest również konieczność uiszczania tzw. opłaty przekształceniowej ${ }^{6}$. Obowiązek jej zapłaty następuje z mocy prawa $\mathrm{z}$ dniem, w którym dochodzi do przekształcenia ${ }^{7}$.

Dopatrzeć się można dużego podobieństwa pomiędzy nią a opłatą roczną za użytkowanie wieczyste ${ }^{8}$. Wspomniane opłaty roczne powinny być co pewien czas urealniane poprzez tzw. ich aktualizację, a odbywa się to w oparciu o art. 77-81 ustawy o gospodarce nieruchomościami ${ }^{9}$. Ta kwestia okazała się wyjątkowo problematyczna na gruncie analizowanej ustawy. Mianowicie, w związku z jej wejściem w życie wielu postępowań aktualizacyjnych nie ukończono. W ustawie przekształceniowej zawarte jednak zostały przepisy przejściowe, regulujące ww. kwestię.

1 Ustawa z dnia 20 lipca 2018 r. o przekształceniu prawa użytkowania wieczystego gruntów zabudowanych na cele mieszkaniowe w prawo własności tych gruntów, Dz. U. z 2018 r. poz. 1716.

2 Wyrok WSA w Krakowie z dnia 4 lutego 2020 r., II SA/Kr 1553/19, LEX nr 2787747.

3 Wyrok NSA z dnia 9 września 2020 r., I OSK 181/20, LEX nr 3057157.

4 Ustawa $\mathrm{z}$ dnia 6 grudnia 2018 r. o zmianie ustawy o przekształceniu prawa użytkowania wieczystego gruntów zabudowanych na cele mieszkaniowe w prawo własności tych gruntów, Dz. U. z 2018 r. poz. 2540.

5 Ustawa z dnia 31 stycznia 2019 r. o zmianie ustawy o gospodarce nieruchomościami oraz ustawy o przekształceniu prawa użytkowania wieczystego gruntów zabudowanych na cele mieszkaniowe w prawo własności tych gruntów, Dz. U. z 2019 r. poz. 270.

6 F. Pietrzyk, Użytkowanie wieczyste nieruchomości publicznych, Warszawa 2020, s. 122-150.

7 Wyrok WSA w Krakowie z dnia 9 lipca 2020 r. II SA/Kr 274/20, LEX nr 3040744.

8 R. Kapkowski, Charakter prawny opłaty przekształceniowej, Krakowski Przegląd Notarialny 2019, R. 4, nr 2, s. 46.

9 Ustawa z dnia 21 sierpnia 1997 r. o gospodarce nieruchomościami, Dz. U. z 2020 r. poz. 65. 
Jednakże przyjęte rozwiązanie budzi kontrowersje. Należy zauważyć, że wejście w życie ww. ustawy zbiegło się z trwającymi już postępowaniami aktualizacyjnymi. Dla tej materii istotne jest, iż w dniu 31 stycznia 2019 r. uchwalona została ustawa o zmianie ustawy o gospodarce nieruchomościami oraz ustawy o przekształceniu prawa użytkowania wieczystego gruntów zabudowanych na cele mieszkaniowe w prawo własności tych gruntów (dalej: ustawa zmieniająca), która weszła w życie w dniu 13 lutego 2019 r. Zgodnie z jej art. 4, jeśli postępowania w sprawie aktualizacji zostały wszczęte po 5 października 2018 r., a wypowiedzenia dotychczasowej wysokości tych opłat nie zostały skutecznie doręczone wszystkim współużytkownikom wieczystym nieruchomości przed 1 stycznia 2019 r., wówczas roczne opłaty przekształceniowe równe są wysokości opłat rocznych z tytułu użytkowania wieczystego, które obowiązywały przed aktualizacją. Dodatkowo nowela założyła, iż postępowania, o których mowa wyżej, niezakończone w dniu wejścia w życie niniejszej ustawy umarza się. Trudno dostrzec cel wprowadzenia tego konkretnego zapisu, a także zakres jego zastosowania. Należy stwierdzić, iż przedmiotowy przepis nie został wystarczająco dopracowany. Jego analiza wywołuje bowiem wiele problemów, w tym związanych ze zgodnością jego treści z Konstytucją $R \mathrm{P}^{10}$.

$\mathrm{W}$ artykule wykazuję, iż doszło tu do naruszenia chronionych $\mathrm{w}$ ramach art. 2 ustawy zasadniczej interesów „w toku”. Nadto nie zostały w wystarczający sposób wyważone interesy stron stosunków cywilnoprawnych, do jakich zalicza się relacje między właścicielami nieruchomości a użytkownikami wieczystymi.

Celem artykułu jest analiza ww. problemu. Omawiam w nim i dokonuję oceny najnowszych zmian legislacyjnych. Metodą badawczą, jaką zastosowano w pracy, jest analiza aktów prawnych, poglądów przedstawicieli doktryny oraz orzecznictwa sądowego.

\section{Aktualizacja opłat rocznych w ustawie o gospodarce nieruchomościami}

Kodeks cywilny (dalej: K.c.) stanowi, iż użytkownicy wieczyści uiszczają przez czas trwania tego prawa opłatę roczną (art. 238 K.c.) ${ }^{11}$. Początek tego trwania wyznacza data powstania prawa użytkowania wieczystego ${ }^{12}$. Regulacja ta uzupełniona jest

10 Konstytucja Rzeczypospolitej Polskiej z dnia 2 kwietnia 1997, tekst jednolity: Dz. U. z 1997 r. Nr 78, poz. 483 z późn. zm.

11 Ustawa z dnia 23 kwietnia 1964 r. - Kodeks cywilny, tekst jednolity: Dz. U z 2020 r. poz. 1740 (dalej: K.c.).

12 Wyrok SN z dnia 4 lutego 2005 r., I CK 512/04, LEX nr 394484. 
o art. 71 ust. 1 u.g.n., który wskazuje, jakie opłaty mają uiszczać ww. podmioty mianowicie poza opłatami rocznymi mają oni uiścić tzw. pierwszą opłatę za użytkowanie wieczyste. Dokładne przepisy odnoszące się do tych opłat ujęte zostały w art. 71-81 u.g.n.

W ustawie o gospodarce nieruchomościami przewidziana jest możliwość ich aktualizacji ${ }^{13}$. W myśl art. 77 u.g.n. wysokość opłaty rocznej z tytułu użytkowania wieczystego nieruchomości gruntowej, z zastrzeżeniem ust. 2 i 2a, podlega aktualizacji nie częściej niż raz na 3 lata, wówczas gdy wartość tej nieruchomości ulegnie zmianie. Zaktualizowaną opłatę roczną ustala się, przy zastosowaniu dotychczasowej stawki procentowej, od wartości nieruchomości określonej na dzień aktualizacji opłaty. Jeżeli wartość nieruchomości gruntowej na dzień aktualizacji opłaty rocznej byłaby niższa niż ustalona w drodze przetargu cena tej nieruchomości w dniu oddania jej w użytkowanie wieczyste, aktualizacji nie dokonuje $\operatorname{się}^{14}$. Odnośnie do nieruchomości oddanych w użytkowanie wieczyste na cele mieszkaniowe przepis stosuje się w okresie 5 lat, licząc od dnia zawarcia umowy o oddanie nieruchomości w użytkowanie wieczyste ${ }^{15}$. W sytuacji, gdy zaktualizowana wysokość opłaty rocznej przewyższa co najmniej dwukrotnie wysokość dotychczasowej opłaty rocznej użytkownik wieczysty uiszcza opłatę roczną w wysokości odpowiadającej dwukrotności dotychczasowej opłaty. Pozostałą do zapłaty kwotę - ponad dwukrotność dotychczasowej - rozkłada się na dwie równe części, które powiększają opłatę roczną w następnych dwóch latach. Opłata ta w trzecim roku od aktualizacji jest równa kwocie wynikającej z tej aktualizacji. Celem tej regulacji jest dostosowanie wysokości opłat rocznych do podlegających ciągłym zmianom cen nieruchomości. Przepisy zawarte w art. 77 u.g.n. pełnią w istocie funkcję ochrony użytkowników wieczystych, ograniczając możliwość dowolnego kształtowania wysokości opłaty rocznej, a także ograniczając liczbę owych zmian w trakcie trwania umowy. Przepisy te więc ograniczają uprawnienia składające się na treść prawa własności ${ }^{16}$. Jako podstawę aktualizacji opłaty rocznej należy przyjąć wartość prawa własności do nieruchomości gruntowej oddanej w użytkowanie wieczyste ustaloną przez rzeczoznawcę majątkowego w formie operatu szacunkowego ${ }^{17}$. Wartość powinna być określona na dzień aktualizacji w ramach

13 Z. Truszkiewicz, Wymagalność opłat z tytułu użytkowania wieczystego $w$ świetle ustawy $z$ dn. 21 sierpnia 1997 r. o gospodarce gruntami, Casus 2000, nr 3, s. 26.

14 Wyrok WSA w Łodzi z dnia 3 grudnia 2019 r., II SA/Łd 569/19, LEX nr 2754231.

15 E. Bończak-Kucharczyk, Ustawa o gospodarce nieruchomościami. Komentarz, Warszawa 2020, s. 516.

16 Wyrok WSA w Łodzi z dnia 3 grudnia 2019 r., II SA/Łd 569/19, LEX nr 2754231.

17 Wyrok WSA w Łodzi z dnia 27 listopada 2019 r., II SA/Łd 540/19, LEX nr 2754140. 
tzw. podejścia porównawczego, uwzględniającego rynkowe transakcje sprzedaży podobnych nieruchomości gruntowych niezabudowanych ${ }^{18}$.

Do aktualizacji nie możne dochodzić częściej niż co 3 lata. Nadto nie można aktualizować opłaty w sytuacji, gdy wartość nieruchomości na dzień aktualizacji miałaby być niższa aniżeli wartość ustalona w drodze przetargu. Jednocześnie nie pozwolono pobierać przez pierwsze dwa lata po zaktualizowaniu opłat rocznych zbyt dużych kwot w sytuacji, gdy zaktualizowana wysokość opłaty rocznej jest wyższa co najmniej dwukrotnie od wysokości dotychczasowej. Powyższe obwarowania są jak najbardziej uzasadnione, albowiem zmiany rynkowej wartości nieruchomości mogą być wywołane przez czynniki, na które użytkownicy wieczyści wpływu nie mają i których nie byli w stanie przewidzieć w momencie zawierania umowy. Powyższe czynniki mogą wpłynąć na wzrost opłat z tytułu użytkowania wieczystego, których wieczyści użytkownicy nie są w stanie opłacać, albowiem zwyżka cen nieruchomości nie musi iść w parze wraz ze wzrostem dochodów ww. podmiotów. Należy podkreślić, iż aktualizacja jest konsekwencją zmian wartości ustalanych przez rzeczoznawców majątkowych, nie natomiast zmian cen. Nowa wysokość zaktualizowanej opłaty zaczyna obowiązywać dopiero od 1 stycznia roku następującego po tym, w którym przeprowadzono wypowiedzenie opłaty dotychczasowej.

Opłaty roczne z tytułu użytkowania wieczystego stanowią ekwiwalent za korzystanie $z$ gruntów podmiotów publicznych i są ustalane jako pewien procent wartości nieruchomości. Warte podkreślenia jest, iż opłata po aktualizacji wiąże każdego kolejnego nabywcę użytkowania wieczystego. Podmiot będący jego nabywcą nie może bronić się twierdzeniem, iż nie wiedział o obowiązku wnoszenia opłat oraz nie posiadał wiedzy o ich wysokości ${ }^{19}$. Regulacje ujęte w u.g.n. bez wątpienia chronią użytkowników wieczystych, ograniczając możliwości dowolnego kształtowania wysokości opłat rocznych oraz ograniczając liczbę zmian w czasie trwania umowy. Można stwierdzić, iż dodatkowo ograniczają uprawnienia składające się na treść prawa własności publicznych właścicieli gruntó $w^{20}$.

Zapewne wolą ustawodawcy było przeprowadzenie przekształcenia prawa użytkowania wieczystego gruntów w prawo własności na dotychczasowych warunkach ekonomicznych zarówno dla gospodarstw domowych, które są głównym beneficjentem dokonywanych zmian, jak i dla podmiotów publicznych, tj. samorządów

$18 \$ 28$ Rozporządzenia z dnia 21 września 2004 r. Rady Ministrów w sprawie wyceny nieruchomości i sporządzania operatu szacunkowego, Dz. U. z 2004 r. Nr 207, poz. 2109 z późn. zm.

19 Wyrok SN z dnia 16 grudnia 1999 r., II CKN 639/98, OSNC 2000, nr 6, poz. 121.

20 Zob. też wyroki WSA w Łodzi: z dnia 17 października 2019 r., II SA/Łd 553/19, LEX nr 2739458; z dnia 22 października 2019 r., II SA/Łd 566/19, LEX nr 2741047; z dnia 13 listopada 2019 r., II SA/Łd 571/19, LEX nr 2749905 i z dnia 3 grudnia 2019 r., II SA/Łd 569/19, LEX nr 2754231. 
terytorialnych, dla których ww. opłaty stanowią zazwyczaj ważną pozycję budżetową $^{21}$. Należy zauważyć, iż wnoszenie opłaty rocznej z tytułu użytkowania wieczystego jest jednym z podstawowych obowiązków użytkownika wieczystego, istotnie odróżniającym je od prawa własności. Z tego też powodu ujmuje się powyższy obowiązek jako element prawnorzeczowego stosunku użytkowania wieczystego. Stanowi on ekwiwalent pieniężny za możliwość korzystania przez użytkownika wieczystego $^{22}$ - z wyłączeniem innych osób - z nieruchomości gruntowej Skarbu Państwa, jednostek samorządu terytorialnego lub ich związków, w granicach określonych przez ustawę i zasady współżycia społecznego oraz umowę o oddanie nieruchomości w użytkowanie wieczyste ${ }^{23}$.

\section{Problem postępowań aktualizacyjnych w toku}

W dniu 5 października 2018 r. weszła w życie ustawa z dnia 20 lipca 2018 r. o przekształceniu prawa użytkowania wieczystego gruntów zabudowanych na cele mieszkaniowe w prawo własności tych gruntów ${ }^{24}$. Jeden z problemów, jaki powstał na jej tle, dotyczy właśnie aktualizacji opłat rocznych z tytułu użytkowania wieczystego. Przedmiotowe przekształcenie, którego dotyczy ww. akt prawny, związane jest z odpłatnością ${ }^{25}$. Opłata przekształceniowa odpowiada wysokości opłaty rocznej z tytułu użytkowania wieczystego, z jaką mielibyśmy do czynienia w dniu przekształcenia (art. 7 ust. 1 i 2 ustawy przekształceniowej) ${ }^{26}$. Opłaty roczne, o czym była mowa wyżej, podlegają aktualizacji w oparciu o art. 77-81 u.g.n. W związku z wejściem w życie wspomnianej ustawy pewna liczba postępowań dotyczących ww. aktualizacji nie została zakończona. W ustawie przekształcenowej znalazły się jednak przepisy przejściowe, które regulują ww. kwestię. Art. 21 ust. 1 analizowanej ustawy wprowadził zasadę, zgodnie z którą wszelkie postępowania dotyczące aktualizacji opłat rocznych z tytułu użytkowania wieczystego, a także ustalenia stawek procen-

21 P. Wancke, Ustawa o przekształceniu prawa użytkowania wieczystego gruntów zabudowanych na cele mieszkaniowe w prawo własności tych gruntów. Komentarz, Warszawa 2019, s. 48.

22 Wyrok SN z dnia 17 grudnia 2008 r., I CSK 244/08, OSNC - Zb. dodatkowy 2009 nr C, poz. 82.

23 Wyrok SN z dnia 25 listopada 2010 r., I CSK 692/09, OSNC - Zb. dodatkowy 2011 nr B, poz. 45.

24 K. Maj, Przekształcenie z dniem 1 stycznia 2019 prawa użytkowania wieczystego gruntów zabudowanych na cele mieszkaniowe w prawo własności tych gruntów, kot Schrődingera i praktyka notarialna, Krakowski Przegląd Notarialny, Kwartalnik Izby Notarialnej w Krakowie 2018, R. 3, nr 3, s. 61.

25 Wyrok WSA w Krakowie z dnia 6 marca 2020 r., II SA/Kr 133/20, LEX nr 2979540.

26 M. Balwicka-Szczyrba, O przekształceniu ex lege użytkowania wieczystego gruntów zabudowanych na cele mieszkaniowe w prawo własności, Rejent 2019, nr 2, s. 13. 
towych tych opłat, wszczęte i niezakończone przed dniem przekształcenia, powinny toczyć się nadal po tym dniu na podstawie przepisów dotychczas obowiązujących, co w praktyce oznacza stosowanie ustawy o gospodarce nieruchomościami.

Uchwalenie ustawy przekształceniowej zbiegło się z toczącymi się już postępowaniami dotyczącymi aktualizacji wartości nieruchomości oddanych w użytkowanie wieczyste. Oznacza to, iż były wszczęte i wszczynano następne procedury aktualizacyjne, celem których stało się podwyższenie wysokości opłat rocznych z tytułu użytkowania wieczystego gruntów zabudowanych na cele mieszkaniowe, a w rezultacie również opłat przekształceniowych ${ }^{27}$. Powyższe działanie samorządów miało oparcie w ustawie o gospodarce nieruchomościami. W przedmiotowej kwestii istotne jest, iż w dniu 31 stycznia 2019 r. uchwalona została ustawa o zmianie ustawy o gospodarce nieruchomościami oraz ustawy o przekształceniu prawa użytkowania wieczystego gruntów zabudowanych na cele mieszkaniowe w prawo własności tych gruntów (dalej: ustawa zmieniająca), która weszła w życie w dniu 13 lutego 2019 r. Zgodnie z jej art. 4:

Jeżeli postępowanie w sprawie aktualizacji opłaty rocznej z tytułu użytkowania wieczystego zostało wszczęte po dniu 5 października 2018 r., a wypowiedzenia dotychczasowej wysokości tej opłaty nie zostały skutecznie doręczone wszystkim współużytkownikom wieczystym nieruchomości przed dniem 1 stycznia 2019 r., roczna opłata przekształceniowa jest równa wysokości opłaty rocznej z tytułu użytkowania wieczystego, która obowiązywała przed aktualizacją.

A nadto: „Postępowania, o których mowa w ust. 1, niezakończone w dniu wejścia $\mathrm{w}$ życie niniejszej ustawy umarza się." Powyższy przepis został dodany w trakcie prac legislacyjnych toczących się nad senackim projektem ustawy o zmianie ustawy o gospodarce nieruchomościami i ustawy o przekształceniu prawa użytkowania wieczystego gruntów zabudowanych na cele mieszkaniowe w prawo własności tych gruntów (druk sejmowy nr 3161 ) $^{28}$. Należy zaznaczyć, iż powyższy projekt nie zawiera uzasadnienia dotyczącego celu wprowadzenia tego konkretnego zapisu oraz zakresu jego zastosowania. Można odnieść wrażenie, iż przedmiotowy przepis nie został wystarczająco dopracowany. Jego interpretacja wywołuje w praktyce wiele problemów, w tym związanych ze zgodnością jego treści z zapisami ustawy zasadniczej.

27 Ł. Sanakiewicz, Przekształcenie prawa użytkowania wieczystego gruntów zabudowanych na cele mieszkaniowe w prawo własności tych gruntów. Komentarz, Warszawa 2019, s. 179.

28 Senacki projekt ustawy o zmianie ustawy o gospodarce nieruchomościami i ustawy o przekształceniu prawa użytkowania wieczystego gruntów zabudowanych na cele mieszkaniowe w prawo własności tych gruntów, Druk nr 3161, http://www.sejm.gov.pl/sejm8.nsf/druk.xsp?nr=3161 [dostęp: 10.09.2020 r.]. 
Wątpliwość pojawiła się już na tle pojęcia „nieruchomości” ujętego w art. 4 ustawy zmieniającej. Z niewyjaśnionych powodów ustawodawca odstąpił od dotychczas obwiązującej zasady, w myśl której sytuacja prawna jednego współużytkownika, uregulowana stosunkiem umownym łączącym go $\mathrm{z}$ właścicielem mienia nieruchomego, nie ingeruje wprost w sytuację innych współużytkowników w kwestii wysokości opłat płaconych przez nich za użytkowanie wieczyste. Prawo to bowiem może przysługiwać określonemu podmiotowi w całości lub może być przedmiotem współużytkowania w częściach ułamkowych. W tej ostatniej sytuacji każdy ze współużytkowników połączony jest $\mathrm{z}$ właścicielem odrębnym stosunkiem prawnym. W tym przypadku należy podkreślić, iż stosunki prawne wynikające $\mathrm{z}$ ww. udziałów są względem siebie odrębne oraz niezależne. $\mathrm{W}$ rezultacie także opłaty roczne są ustalane niezależnie dla każdego ze współużytkowników wieczystych. W tej sytuacji podmiot publiczny będący właścicielem nieruchomości, pragnąc przeprowadzić aktualizację, kieruje wypowiedzenia do każdego ze współużytkowników wieczystych oddzielnie, przedstawiając propozycję nowej wysokości tej opłaty w stosunku do udziału w prawie użytkowania wieczystego. Przedmiotowe wypowiedzenie powinno być dokonane $\mathrm{w}$ formie pisemnej $\mathrm{w}$ terminie do dnia 31 grudnia roku poprzedzającego. Należy podkreślić, iż współużytkownik wieczysty, pragnący zakwestionować wysokość nowej opłaty, składa wniosek do samorządowego kolegium odwoławczego. Od orzeczenia ww. organu stronom przysługuje sprzeciw. Dokonanie wniesienia jest równoznaczne z żądaniem przekazania sprawy do sądu powszechnego właściwego ze względu na miejsce położenia przedmiotowej nieruchomości. Aktualizacja prowadzona jest w związku z tym indywidualnie w stosunku do każdego ze współuczestników, natomiast wynik ww. postępowania wywołuje skutek jedynie wobec tych współuczestników wieczystych, którzy brali udział w tym postępowaniu ${ }^{29}$. W rezultacie sytuacja prawna indywidualnego współużytkownika nie wpłynie w bezpośredni sposób na sytuację wszystkich pozostałych współużytkowników w kwestii wysokości opłat płaconych z tytułu użytkowania wieczystego. Na skutek powyższego wysokość opłat, które obciążają poszczególnych współużytkowników wieczystych, może być różna. Obciążają one indywidualnie każdego współużytkownika proporcjonalnie do wielkości przysługującego mu udziału ${ }^{30}$. Prowadzi to do wniosku, iż jeśli nieruchomość zabudowana jest budynkiem mieszkalnym wielorodzinnym $\mathrm{z}$ wyodrębnionymi lokalami mieszkalnymi, to w sytuacji, kiedy nawet jeden z właścicieli lokali, któremu

29 Wyrok SA w Warszawie z dnia 17 marca 2015 r., VI ACa 765/14, LEX nr 1667675.

30 Postanowienie SN z dnia 30 marca 2011 r., III CZP 3/11, http://www.sn.pl/Sites/orzecznictwo/ Orzeczenia1/III\%20CZP\%203-11.pdf [dostęp: 10.09.2020 r.]. 
przysługuje udział we współużytkowaniu wieczystym gruntu pod budynkiem, nie otrzymał wypowiedzenia opłaty rocznej przed datą 1 stycznia 2019 r., to wówczas dla wszystkich współużytkowników wieczystych roczna opłata przekształceniowa odpowiada wysokości opłaty rocznej z tytułu użytkowania wieczystego obowiązującej przed aktualizacją. Natomiast w przypadkach, gdy postępowania aktualizacyjne były w toku (np. w związku ze złożeniem wniosku do samorządowego kolegium odwoławczego), zostają one umorzone. Problemów interpretacyjnych można również doszukiwać się w zakresie zastosowania analizowanej regulacji. Analizując art. 4 ust. 2 w zw. z art. 4 ust. 1 ustawy zmieniającej, dostrzec można trzy podstawy umorzenia postępowania aktualizacyjnego: a) pierwsza dotyczy wszczęcia postępowania po dniu 5 października 2018 r.; 2) druga związana jest z brakiem skutecznego doręczenia wypowiedzenia dotychczasowej wysokości opłaty wszystkim współużytkownikom wieczystym nieruchomości przed dniem 1 stycznia 2019 r.; 3) trzecia uwarunkowana jest niezakończonym postępowaniem w dacie wejścia w życie ustawy zmieniającej, tj. w dniu 13 lutego 2019 r. Takie stanowisko dostrzec można $\mathrm{w}$ orzecznictwie sądów administracyjnych ${ }^{31}$. W przedmiotowej kwestii również zastosować można inną interpretację omawianego przepisu, w myśl której obejmuje on swoją hipotezą wszelkie postępowania dotyczące aktualizacji wszczętych po wejściu w życie ustawy przekształceniowej, a nie zakończonych przed 13 lutego 2019 r. W takim wypadku dla umorzenia postępowania wystarczające jest tylko ustalenie, iż postępowanie aktualizacyjne zostało wszczęte po dniu 5 października 2018 r. i nie zostało ukończone w dniu wejścia w życie ustawy zmieniającej. Natomiast okoliczność dotycząca tego, czy wszyscy współużytkownicy wieczyści nieruchomości odebrali wypowiedzenia dotychczasowej wysokości opłaty rocznej przed dniem 1 stycznia 2019 r. nie jest w tym wypadku decydująca. Powyższe prowadzi do wniosku, iż zakres postępowań, które wszczęto po dniu 5 października 2018 r., podlegających umorzeniu z mocy wspomnianego przepisu, będzie zdecydowanie szerszy.

Należy podkreślić, iż ustawodawca wprowadzając do systemu prawnego art. 4 ustawy zmieniającej (z mocą obowiązującą od dnia 13 lutego 2019 r.), zaingerował $\mathrm{z}$ mocą wsteczną $\mathrm{w}$ bieg tych postępowań. Uczynił to wbrew regule przyjętej pierwotnie w art. 21 ust. 1 ustawy przekształceniowej, określającej byt prawny postępowań aktualizacyjnych w toku. Niewątpliwie podmioty publiczne w przedmiotowej kwestii zostały zaskoczone rozwiązaniami nakazującymi umorzenie postępowań

31 Por. wyrok WSA w Krakowie z dnia 3 marca 2020 r., II SA/Kr 105/20, LEX nr 2846472; wyrok WSA w Łodzi z dnia 24 stycznia 2020 r., II SA/Łd 559/20, LEX nr 2779410; wyrok WSA w Krakowie z dnia 24 czerwca 2020 r., II SA/Kr 1179/19, LEX nr 3035580. 
aktualizujących i w konsekwencji utrzymującymi wysokość opłat na poziomie niezależnym od wartości rynkowej nieruchomości. Trzeba stwierdzić, iż przedmiotowa regulacja skutkuje nieuzasadnionym obniżeniem opłat bądź też nieuzasadnionym zakończeniem postępowań aktualizacyjnych dotyczących wszystkich współużytkowników wieczystych konkretnej nieruchomości. Powyższe godzi w samodzielność finansową podmiotów publicznych i jest nadmierną oraz nieuzasadnioną ingerencją ustawodawcy.

Można dostrzec tu brak zgodności z art. 167 ust. 1 i 2, a także art. 165 ust. 1 Konstytucji RP, gwarantującymi podmiotom publicznym własność oraz inne prawa majątkowe, a także zachowanie dochodów na poziomie niezbędnym do wykonywania przypadających im zadań. Niewątpliwie dochody z tytułu opłat rocznych za użytkowanie wieczyste były istotną częścią budżetów samorządów terytorialnych. To ostatnie daje podstawę do stwierdzenia, iż mamy tu do czynienia z naruszeniem ich chronionych w ramach art. 2 Konstytucji RP interesów „w toku”. W przedmiotowej sprawie nie dokonano bowiem właściwego wyważenia interesów stron cywilnoprawnych stosunków, do jakich należy zaliczyć relacje między właścicielami nieruchomości a użytkownikami wieczystymi. Zasada demokratycznego państwa prawnego służąc ochronie interesów w toku, zapewnia ochronę jednostek w przypadkach, w których dokonała ona określonego przedsięwzięcia na gruncie dotychczasowych regulacji. Mimo iż ww. zasada nie jest zasadą bezwzględną, ustawodawcę obciąża szczególny obowiązek ochrony interesów w toku w przypadku zaistnienia następujących przesłanek: „1) przepisy prawa wyznaczają pewien horyzont czasowy dla realizowania określonych przedsięwzięć; 2) dane przedsięwzięcie ma charakter rozłożony w czasie; 3 ) jednostka faktycznie rozpoczęła realizację danego przedsięwzięcia w okresie obowiązywania danej regulacji”" ${ }^{32}$. Należy zaznaczyć, iż przepis prawny pociągający za sobą stosowne skutki finansowe dla podmiotu publicznego nie powinien budzić tak znacznej ilości wątpliwości co do jego interpretacji. Ustawodawca zobligowany jest do formułowania regulacji prawnych w sposób poprawny, jasny oraz precyzyjny. Źle skonstruowany przepis prawny prowadzi do niepewności sytuacji adresatów normy oraz pozostawienie jej kształtowania organom stosującym prawo. Należy podkreślić, iż w analizowanej materii postępowanie ustawodawcy różnicuje w sposób nieuzasadniony sytuację prawną samych użytkowników wieczystych, dokonując uprzywilejowania grupy użytkowników wieczystych, co do których postępowanie w sprawie aktualizacji zostało wszczęte po dniu 5 października 2018 r., w stosunku do pozostałych użytkowników wieczystych, wobec których postępowanie ww. zostało wszczęte również w $2018 \mathrm{r}$. 
(jednakże do dnia 5 października 2018 r.). Kryterium powyższego zróżnicowania, tj. moment doręczenia wypowiedzenia dotychczasowej wysokości opłaty, jest niezależne od niczyjej woli, a jedynie od przypadku ${ }^{33}$.

Podniesione powyżej wątpliwości, potwierdzają fakt naruszenia chronionych w ramach art. 2 ustawy zasadniczej interesów „w toku”.

\section{Przesłanki skuteczności aktualizacji opłat rocznych z tytułu użytkowania wieczystego - stanowisko ustawodawcy}

Celem rozwiązania zawartego w art. 4 ustawy z dnia 31 stycznia 2019 r. o zmianie ustawy o gospodarce nieruchomościami oraz ustawy o przekształceniu prawa użytkowania wieczystego gruntów zabudowanych na cele mieszkaniowe w prawo własności tych gruntów było zapewne ujednolicenie sytuacji prawnej wszystkich podmiotów będących współużytkownikami wieczystymi konkretnej nieruchomości. Zgodnie ze stanowiskiem ustawodawcy wyżej wspomniane orzeczenia sądów nie będą miały zastosowania do sytuacji prawnej, która została ukształtowana na skutek przekształcenia ex lege, a konsekwencja finansowa, tj. wysokość opłaty za nabycia prawa własności, staje się w zasadzie nieodwracalna. W rezultacie postępowania niektórych podmiotów publicznych skutkowały tym, iż osoby korzystające $\mathrm{z}$ tego samego gruntu i będące $\mathrm{w}$ takiej samej sytuacji prawnej uzyskałyby prawo własności ww. gruntu za rażąco odmienne wysokości opłaty. Zdaniem ustawodawcy szczególnie znamienna dla przedmiotowej kwestii była znaczna aktywność wielu jednostek samorządu terytorialnego w czasie bezpośrednio poprzedzającym uwłaszczenie ex lege w zakresie aktualizacji opłat. Działania te miały w stosunku do użytkowników wieczystych wyjątkowe znaczenie, albowiem determinowały w długoletniej perspektywie wysokość zobowiązań finansowych za przekształcenie prawa użytkowania wieczystego w prawo własności. Rezultatem tych działań było często wybiórcze obejmowanie postępowaniem aktualizacyjnym tylko niektórych współużytkowników wieczystych w ramach jednej nieruchomości, którym doręczano wypowiedzenia. W wyniku powyższego tylko pewna część dotychczasowych użytkowników wieczystych zobowiązana zostałaby do uiszczania opłat przekształceniowych w większym wymiarze niż podmioty, którym nie złożono stosownego oświadczenia woli. Stan taki byłby niezgodny z konstytucyjną zasadą równości wobec prawa wszystkich podmiotów będących stronami tożsame-

33 Pismo Rzecznika Praw Obywatelskich z dnia 16 lipca 2020 r., znak: IV.7000.500.2019.DZ. 
go stosunku obligacyjnego ze Skarbem Państwa czy też jednostką samorządu terytorialnego. A taka sytuacja uzasadniałaby konieczność prawotwórczej interwencji ustawodawcy. Bez wątpienia należy stwierdzić, że w sytuacji zmiany wartości nieruchomości uzasadniającej aktualizację określenie nowej wysokości zobowiązania z tytułu użytkowania wieczystego, a w konsekwencji również z tytułu przekształcenia winno wywołać skutek do wszystkich podmiotów będących współużytkownikami wieczystymi tego samego gruntu. Należy podkreślić, iż nie istnieją żadne przesłanki, czy to natury prawnej czy też faktycznej, umożliwiające podmiotom publicznym różnicowanie sytuacji prawnej tych podmiotów, a w szczególności nie istnieje podstawa uzasadniająca stosowanie odmiennej podstawy wymiaru opłaty z tytułu korzystania z gruntu, a w konsekwencji wymiaru opłaty za własność tego gruntu. Zdaniem ustawodawcy omawianej sytuacji nie powinno się porównywać $\mathrm{z}$ aktualizacją opłaty inicjowaną $\mathrm{w}$ wypadkach, kiedy użytkowanie wieczyste nie podlega przekształceniu w prawo własności. Jeśli bowiem ww. prawo nadal istnieje, brak jest barier do ujednolicenia w krótkim czasie wysokości opłat rocznych, również z inicjatywy samego użytkownika wieczystego. Ustawodawca założył, iż bez wątpienia naganna praktyka stosowania przez niektóre podmioty publiczne - w czasie poprzedzającym ostatnie uwłaszczenie - rygorystycznych kryteriów przy składaniu oświadczeń o wypowiedzeniu opłaty rocznej, uzasadniała objęcie ww. podmiotów wyjątkową ochroną przed konsekwencjami działań, godzących ewidentnie w zasady współżycia społecznego. Faktem jest, iż w okresie między przyjęciem przez parlament ustawy o przekształceniu z 2018 r. a dniem jej wejścia w życie podmioty publiczne posiadały możliwość przeprowadzenia precyzyjnej oceny stanu mienia wchodzącego do ich zasobów, a co za tym idzie - podjęcia czynności ukierunkowanych na optymalizację dochodów z tytułu opłat od użytkowania wieczystego. Nie można zaprzeczyć i temu, że względy prawidłowej gospodarki przemawiały za dokonaniem aktualizacji w stosunku do wszystkich podmiotów będących współużytkownikami wieczystymi konkretnej nieruchomości. Albowiem takie postępowanie jest gwarantem rekompensaty kosztów postępowania aktualizacyjnego oraz maksymalizacji wpływów pochodzących $\mathrm{z}$ danej nieruchomości, na czym zarówno Skarbowi Państwa, jak i jednostkom samorządu terytorialnego powinno szczególnie zależeć. Ustawodawca nie dostrzega gospodarczego uzasadnienia dla wybiórczego składania oświadczeń o wypowiedzeniu opłaty rocznej tylko w stosunku do wybranych podmiotów będących współużytkownikami wieczystymi. Jego zdaniem przyjęta koncepcja sprowadzająca się do pozbawienia skutków prawnych wypowiedzeń opłaty rocznej przeprowadzonych po dniu 5 października 2018 r. tylko w stosunku do części współużytkowników wieczystych tej samej nieruchomości urealnia zasadę równego traktowania, nadto 
służy pogłębieniu zaufania obywateli do władzy publicznej, a także sprzyja kreowaniu warunków do podejmowania przez organy podmiotów publicznych czynności wolnych od dyskryminacji uczestników obrotu prawnego. Zdaniem ustawodawcy doprowadzenie do ograniczenia skutków prawnych jedynie do postępowań aktualizacyjnych wszczętych po wejściu ustawy o przekształceniu z 2018 r. w życie w racjonalny sposób wyważyło interesy majątkowe podmiotów publicznych oraz uwzględniło ochronę słabszych uczestników obrotu ${ }^{34}$. Niemniej trudności w wykładni omawianego przepisu pozostały. Nie można podzielić poglądu ustawodawcy, iż został on skonstruowany jasno oraz precyzyjnie, a podnoszone krytyczne głosy pochodzą jedynie ze strony tych samorządów, którym doskwiera fakt obniżenia wpływów z zakładanych podwyżek opłat.

\section{Zakończenie}

Ustawa o przekształceniu nie likwiduje prawa użytkowania wieczystego jako instytucji prawa cywilnego. Z dniem 1 stycznia 2019 r. jedynie niektóre, indywidualne prawa użytkowania wieczystego uległy z mocy prawa przekształceniu w prawo własności ${ }^{35}$. Sama prawo jako instytucja prawa cywilnego nie uległo likwidacji, a przepisy je regulujące pozostają $\mathrm{w}$ dalszej mierze $\mathrm{w}$ mocy ${ }^{36}$. „Zupełna eliminacja użytkowania wieczystego nie jest jednak aktualnie możliwa $\mathrm{z}$ uwagi na brak w systemie praw rzeczowych alternatywnych praw pozwalających na długofalowe, stabilne inwestowanie w cudzą nieruchomość" ${ }^{37}$. Zasadą jest, że przekształcenie użytkowania wieczystego w prawo własności następujące na podstawie ustawy z dnia 20 lipca 2018 r. o przekształceniu jest odpłatne ${ }^{38}$.

Ustawodawca, wiedząc, że opłaty roczne podlegają aktualizacji, a do momentu wejścia w życie przedmiotowej ustawy znaczna liczba postępowań w sprawie aktualizacji nie była zakończona, przewidział w ww. ustawie rozwiązania przejściowe,

34 Pismo Ministra Rozwoju z dnia 24 sierpnia 2020 r., znak: DN-I.750.197.2020.

35 H. Ciepła, Użytkowanie wieczyste skutki prawne wygaśnięcia przekształcenie w prawo własności i jego wpis do księgi wieczystej. Praktyka i orzecznictwo, Warszawa 2019, s. 160.

36 M. Tollik, Objęcie nieruchomości niezabudowanej skutkami ustawy o przekształceniu prawa użytkowania wieczystego gruntów zabudowanych na cele mieszkaniowe w prawo własności tych gruntów, Palestra 2020, nr 2, s. 56.

37 Uzasadnienia projektu ustawy, Druk sejmowy nr 2673, http://www.sejm.gov.pl/sejm8.nsf/druk. xsp?nr=2673 [dostęp: 19.10.2020 r.].

38 E. Klat-Górska, Przekształcenie użytkowania wieczystego we własność. Zagadnienia prawne, Warszawa 2019, s. 55. 
regulujące byt prawny postępowań aktualizacyjnych wszczętych i niezakończonych przed dniem przekształcenia (art. 21 ustawy przekształceniowej).

Istota art. 21 ust. 1 ustawy przekształceniowej sprowadza się do tego, że postępowania w sprawach aktualizacji opłat rocznych z tytułu użytkowania wieczystego, a także aktualizacji bądź też ustalenia stawek procentowych tych opłat, wszczęte oraz niezakończone przed dniem przekształcenia, toczą się nadal po tym dniu na podstawie przepisów dotychczasowych - tj. przepisów u.g.n.

Zwrócić należy uwagę na sprzeczne działania ustawodawcy, który wbrew przyjętej zasadzie ujętej w art. 21 ust. 1 ustawy przekształceniowej, określającej byt prawny postępowań dotyczących aktualizacji w toku, wprowadzając do obrotu prawnego art. 4 ustawy zmieniającej (z mocą obowiązującą od dnia 13 lutego 2019 r.), dokonał ingerencji z mocą wsteczną w bieg tychże postępowań. Art. 4 ustawy z dnia 31 stycznia 2019 r. o zmianie ustawy o gospodarce nieruchomościami oraz ustawy o przekształceniu prawa użytkowania wieczystego gruntów zabudowanych na cele mieszkaniowe w prawo własności tych gruntów (Dz. U. z 2019 r. poz. 270) stanowi źródło wielu wątpliwości.

Reasumując, należy stwierdzić, iż omawiana regulacja:

1) zaskoczyła jednostki samorządu terytorialnego w ramach realizacji zamierzeń o charakterze cywilnoprawnym i w ramach cywilnych relacji z innymi podmiotami poprzez rozwiązanie nakazujące umorzenie postępowań aktualizujących wartość nieruchomości;

2) w rezultacie utrzymała wysokość opłat na poziomie nieskorelowanym z wartością rynkową nieruchomości;

3) prowadzi w konsekwencji do nieuzasadnionego obniżenia opłat;

4) skutkuje nieuzasadnionym zakończeniem postępowań aktualizacyjnych w stosunku do wszystkich współużytkowników wieczystych danej nieruchomości;

5) stanowi nadmierną i niczym nieuzasadnioną ingerencję ustawodawcy w samodzielność finansową jednostek samorządu terytorialnego;

6) różnicuje w niezrozumiały sposób sytuację prawną użytkowników wieczystych, tworząc dwie grupy. Kryterium tego różnicowania, tj. moment doręczenia wypowiedzenia dotychczasowej wysokości opłaty, jest niezależne od niczyjej woli, a wyłączenie od przypadku.

Powyższe pozwala stwierdzić, iż ewidentnie doszło tu do naruszenia chronionych w ramach art. 2 Konstytucji RP interesów „w toku”.

Zasada ochrony interesów w toku służy ochronie jednostki w wypadkach, kiedy zainicjowała ona określone przedsięwzięcia na gruncie dotychczasowych przepisów. Mimo iż ww. zasada nie ma statusu bezwzględnego, na ustawodawcy spoczywa 
szczególny obowiązek ochrony interesów będących w toku w sytuacji zaistnienia określonych przesłanek ${ }^{39}$.

Reasumując, rozwiązania proponowane przez ustawodawcę skutkujące określonymi konsekwencjami finansowymi dla jednostek samorządu terytorialnego nie mogą generować tak znacznej ilości wątpliwości co do jej wykładni. Tworzenie prawa związane jest $\mathrm{z}$ formułowaniem przepisów w sposób właściwy, zrozumiały oraz dokładny. Jest to obowiązek ciążący na prawodawcy, który ma kreować przepisy prawa w możliwie optymalny sposób, zarówno pod względem ich treści, jak i formy. Brak jasności przedmiotowego przepisu w praktyce oznacza stan niepewności, gdy idzie o sytuację prawną jej adresatów oraz oddanie jej kształtowania organom stosującym prawo, a to z kolei rodzić będzie rozbieżne, sprzeczne ze sobą stanowiska.

Uwzględniając powyższe kwestie oraz fakt, iż spora grupa użytkowników wieczystych nie została objęta przekształceniem, należy żywić nadzieję, iż ustawodawca podejmując w przyszłości działania uwłaszczeniowe w stosunku do pozostałej jeszcze grupy, ustrzeże się błędów wyżej omówionych.

\section{Bibliografia}

Balwicka-Szczyrba M., O przekształceniu ex lege użytkowania wieczystego gruntów zabudowanych na cele mieszkaniowe w prawo własności, Rejent 2019, $\mathrm{nr} 2$.

Bończak-Kucharczyk E., Ustawa o gospodarce nieruchomościami. Komentarz, Warszawa 2020. Ciepła H., Użytkowanie wieczyste skutki prawne wygaśnięcia przekształcenie w prawo własności i jego wpis do ksieggi wieczystej. Praktyka i orzecznictwo, Warszawa 2019.

Jaworski J., Prusaczyk A., Tułodziecki A., Wolanin M., Ustawa o gospodarce nieruchomościami. Komentarz, Warszawa 2017.

Kapkowski R., Charakter prawny opłaty przekształceniowej, Krakowski Przegląd Notarialny 2019, R. 4, nr 2.

Klat-Górska E., Przekształcenie użytkowania wieczystego we własność. Zagadnienia prawne, Warszawa 2019.

Maj K., Przekształcenie $z$ dniem 1 stycznia 2019 prawa użytkowania wieczystego gruntów zabudowanych na cele mieszkaniowe w prawo własności tych gruntów, kot Schrődingera i praktyka notarialna, Krakowski Przegląd Notarialny 2018, R. 3, nr 3.

Pietrzyk F., Użytkowanie wieczyste nieruchomości publicznych, Warszawa 2020.

Pismo Ministra Rozwoju z dnia 24 sierpnia 2020 r., znak: DN-I.750.197.2020.

39 Przekształcenie użytkowania wieczystego nieruchomości mieszkaniowej w prawo własności - RPO sugeruje zmiany w przepisach, https://mojafirma.infor.pl/nieruchomosci/prawo/4642588, Przeksztalcenieuzytkowania-wieczystego-nieruchomosci-mieszkaniowej-w-prawo-wlasnosci-RPO-sugeruje-zmianyw-przepisach.html [dostęp: 10.10.2020 r.]. 
Pismo Rzecznika Praw Obywatelskich z dnia 16 lipca 2020 r., znak: IV.7000.500.2019.DZ.

Przekształcenie użytkowania wieczystego nieruchomości mieszkaniowej w prawo własności $R P O$ sugeruje zmiany $w$ przepisach, https://mojafirma.infor.pl/nieruchomosci/prawo/ 4642588,Przeksztalcenie-uzytkowania-wieczystego-nieruchomosci-mieszkaniowej-w -prawo-wlasnosci-RPO-sugeruje-zmiany-w-przepisach.html [dostęp: 10.10.2020 r.].

Sanakiewicz Ł., Przekształcenie prawa użytkowania wieczystego gruntów zabudowanych na cele mieszkaniowe w prawo własności tych gruntów. Komentarz, Warszawa 2019.

Senacki projekt ustawy o zmianie ustawy o gospodarce nieruchomościami i ustawy o przekształceniu prawa użytkowania wieczystego gruntów zabudowanych na cele mieszkaniowe w prawo własności tych gruntów, Druk nr 3161, http://www.sejm.gov.pl/sejm8.nsf/ druk.xsp?nr=3161 [dostęp: 10.09.2020 r.].

Siwowski M., Aktualizacja opłaty rocznej z tytułu użytkowania wieczystego - wybrane zagadnienia praktyczne sądowego etapu postępowania, Palestra 2019, nr 1-2.

Tollik M., Objęcie nieruchomości niezabudowanej skutkami ustawy o przekształceniu prawa użytkowania wieczystego gruntów zabudowanych na cele mieszkaniowe w prawo własności tych gruntów, Palestra 2020, nr 2.

Truszkiewicz Z., Wymagalność opłat z tytułu użytkowania wieczystego $w$ świetle ustawy $z$ dn. 21 sierpnia 1997 r. o gospodarce gruntami, Casus 2000, nr 3.

Uzasadnienia projektu ustawy, Druk sejmowy nr 2673, http://www.sejm.gov.pl/sejm8.nsf/ druk.xsp?nr=2673 [dostęp: 19.10 .2020 r.].

Wancke P., Ustawa o przekształceniu prawa użytkowania wieczystego gruntów zabudowanych na cele mieszkaniowe w prawo własności tych gruntów. Komentarz, Warszawa 2019. 
